\title{
Perceived Trust and Payment Methods: An Empirical Study of MarkaVIP Company
}

\author{
Mahmoud Maqableh1, Ra'ed Moh'd Taisir Masa'deh1, Rifat O. Shannak1, Khalid M. Nahar² \\ ${ }^{1}$ Management Information Systems, Faculty of Business, The University of Jordan, Amman, Jordan \\ ${ }^{2}$ Computer Science, Faculty of Information Technology and Computer Science, Yarmouk University, Irbid, \\ Jordan \\ Email: maqableh@ju.edu.jo
}

Received 14 September 2015; accepted 1 November 2015; published 13 November 2015

Copyright (C) 2015 by authors and Scientific Research Publishing Inc.

This work is licensed under the Creative Commons Attribution International License (CC BY). http://creativecommons.org/licenses/by/4.0/

(c) (i) Open Access

\section{Abstract}

This empirical study focused on investigating the perceived trust surrogated by a number of hypothesized factors and its effect on the choice of method of payment. The data were collected using a questionnaire, as the instrument for the primary data collection, with total collected back responses of 214 from customers of MarkaVIP. Structural equation modeling technique was used to fully analyze the data in order to determine what level of the relationship between the constituting factors of the perceived trust and the method of payment. The main findings were related to confirming the seven main hypotheses of the research that were related to testing if some factors were important to forming perceived trust by customers. Four factors (reputation, security, familiarity, and ease of use) were found to have a positive effect and the remaining three were not (privacy, size and usefulness). In addition, having perceived trust meant no preference to any method of payment by the customers.

\section{Keywords}

E-Payment, Perceived Trust, EPS, E-Commerce, Security, Structural Equation Modeling

\section{Introduction}

Electronic commerce (E-commerce) emerged due mainly to the advent of the Internet and its many characteristics that ease real-time information interchange. Internet facilitated many business activities like: advertising, querying, negotiation, ordering and payment. When using this great facility, accuracy and security become critical in payment systems because all transactions will be completed through the network system [1]. The network system faces many threats even when all aspects of security are applied. For example, PayCash is an internet 
payment system designed to preserve security and privacy. PayCash had special techniques to generate trustworthy records of transactions and fraud detection [2]. Trust issues that are necessary for an electronic payment system to be utilized as a common medium of financial transactions are: identification, authentication, accountability, authorization, and availability [3] [4]. Some payment systems like the ones on mobile can provide independence in time and place, remote payments, availability, and queuing avoidance [5] [6]. Currently, payment systems support environments where traditional payment systems could not function properly.

Experts usually divide payment systems into four categories: Credit Card Payment System, Online Electronic Cash System, Electronic Cheque System and Smart Cards based Electronic Payment System. The said categories can be distinguished based on what is being transmitted over the network and could be evaluated based on their requirements such as: security, acceptability, convenience, cost, anonymity, control, and traceability [7] [8]. Subsequent to Sumanjeet's (2009) stated methods of e-payment systems and their challenges, there had been a discussion covering different aspects including security measurements which had been suggested for these aspects as well as conducting possible solutions [7]. For example, when using debit cards, it is easier to perform many payment transactions for different pay services but, convincing the majority of customers to use this method of payment requires much convincing as people at large are still not satisfied and would prefer to perform payments physically which raise the consideration of trust factor in those plastic cards. One possible reason behind this is the lack of trust in some e-payment transactions due to frequent malfunctioning, potential fraud, and the unavailability of e-payment machines on demand which raises uncertainty among the public about the usefulness of such new technology [9]. However, some innovative technologies like web ATMs which deploy a card with an integrated chip along with a smart card reader on the Web, may steer the banking system for better changes that are acceptable and meet the expectations of the public, basically on the C2C model [10]. However, more work has to be done on security issues in order to persuade customer of the security and safety for sending sensitive information online. Therefore, focusing on some aspects of security like: privacy, encryption, authentication and authorization contributes to encouraging customers to make on-line payments and perform financial transactions electronically which help to enhance trustfulness. In e-commerce, physical sense of the product usually does not occur at the time of transaction. Therefore, issues of trust and acceptance become critical for the customer. Meanwhile, the main objectives of Electronic Payment System (EPS) are to enhance efficiency, assure security, gain customer convenience and facilitate ease of use [11].

On studying customer expectation with EPSs in Malaysia for example, factors that were found to mostly affect the firms' perceptions were flexibility followed by functionality, data management, privacy and security of EPS. Level of EPS prediction was found to be affected mostly by three main factors namely: functionality, privacy and security [12] [13]. On mobile payment, the customer behavioral intention is highly affected by the trust factor combined with the negative and positive valence of the actual use [14]. When considering the architecture of the payment system, it was clearly indicated that the smooth functioning and simplicity of the national payment highly affected the economy which raised the simplicity as another important factor [15]. The major banks in every country that are connected over a communication network, have to set up the global payment and settlement for the currency of that country, besides the need for having a robust banking system, tight risk control and sophisticated technology [16]. For mobile payments using Virtual Social Networks (VSN), other important factors arise which have to be added to the payment model such as: external influences, ease of use, usefulness, attitude, trust and risk as they might increase the intention of use by the customer [17].

\section{Theoretical Background and Hypotheses Development}

Gefen (2000) showed that trust and familiarity influence E-commerce. Based on a survey study, two main aspects of book selling on the internet were highly affected by the trust and familiarity of the internet vendor. These were inquiry and purchase aspects [18]. Moreover, the survey study model showed that E-commerce would be enhanced in a complex social environment, and that the behavioral intentions were highly affected by trust and familiarity. Tan and Thoen (2001) introduced a generic model of trust for E-commerce where one can start a transaction if he/she trusts the model over his/her own personal level of trust. This depends on individuals involved in the transaction and its type [19]. They argued for two main factors of transaction trust level being the other party trust and the control mechanisms trust. Both factors have objective and subjective aspects. The study focused on two main activities which were the electronic payment and the cross-border trading.

Chellappa and Pavlou (2002) studied the relationship between consumer perceived information security and 
E-commerce trust transaction [20]. Their study was carried out on 179 consumer and the results showed a minimal effect of financial liability on customers' trust in E-commerce, while their research focus was on the role of perceived security in building E-commerce trust. Koufaris and Hampton-Sosa (2004) proposed a model to investigate the trust development in web-based company after the first visit by the customers [21]. Testing the model was carried out using a questionnaire. The outcomes proved that the perceived company reputation and the willingness to customize products and service have highly impacted the initial trust. Moreover, usefulness, ease of use, and security control were also found to have high impacts on the initial trust. No support for the presumed hypothesized effect where found on the initial trust.

Liu and collaborators (2005) conducted a study based on a model that was concerned with the individuals' privacy and its relationship with the behavioral intention when initiating online transactions [22]. A total of 200 customers were investigated for two E-commerce sites that differed only in their privacy dimensions. The model was strongly supported by the study. Meanwhile, Tsiakis and Sthephanides (2005) implicated that the trust and security were two important and essential deciding factors for any E-payment system to be used as a medium for financial transactions [3]. Teo and Liu (2007) carried out a comparative study in the United States, Singapore and China to investigate the antecedents and consequences of consumer trust [23]. They discovered that reputation and system assurance of the Internet vendor had positive relationship with the consumer trust. The perceived risk was found to have a negative relationship with consumer trust while the relationship was rather positive with the attitude.

Kim and collaborators (2008) developed a theoretical framework to investigate the trusting process that a consumer uses when purchasing from a given site [24]. The suggested model was tested using Structural Equation Modeling technique (SEM). The data set was behavioral and data were collected via a web survey. The study outcomes showed that consumers trust and perceived risk strongly influenced their decisions when purchasing through the Internet. Moreover the study showed that trusting the Website was highly influenced by the consumer disposition to trust, reputation, privacy concerns, security concerns, the information quality of the Website, and the company's reputation. Meanwhile, the existence of a third-party mediator was found to have a relatively little impact on consumer trust.

In [25] discuss factors that influence E-payment system adoption and classified these factors into six dimensions; security, ease of use, trust, interporability, regularity issues, and added service. He concluded that, based on these factors much efforts are required in order to come up with a common trust between sellers and buyers for online shopping. Later on, in [26] the factors that affected the trust among the Virtual Community (VC) members and their impact on $\mathrm{C} 2 \mathrm{C}$ websites or vendors were analyzed. Based on formation mechanism, they proposed a model of trust in VCs. The data used for testing the model were collected from Tao-bao VC. The results of the study showed that the important antecedents of trust between VCs members were; familiarity, perceived similarity, structural assurance, and trust propensity. Moreover, trust in the members ability was found to highly affect ability, integrity, and benevolence in the vendor/website. In addition, trusting the members integrity and benevolence stimulated purchase intention while, trust in vendor/website's ability has positively affected information regaining intention and the purchase intention. Kim and collaborators, (2010) indicted that the strong predictors of the intention to use mobile-payment were; perceived ease of use and usefulness [27].

Kim and collaborators (2011) conducted a structural equation model to examine the factors that affect trust, satisfaction, and loyalty in a tourism management system for online shopping in south-Korea [28]. Using the internet search, a 340 questionnaires were collected online. They concluded that navigation functionality and perceived security have positively affected trust while transaction cost had no effect on trust. Moreover, it was clear from the analysis of collected data that satisfaction had a positive impact on trust and that trust in turn, did affect customer loyalty in online shopping of tourism products and services.

Kim and Park (2012) studied and identified the main characteristics that affected Korean consumers trust in social commerce (s-commerce) [29]. The key factors of the reputation, size, information quality, transaction safety, communication, economic feasibility, and word-of-mouth (WOM) referrals were identified and the study assessed their impact on trust performance which translates into the actual purchase intentions and the WOM intentions. Data were collected from 371 s-commerce users who have all emphasized that all previous factors except economic feasibility highly affect trust. Meanwhile, trust had a large influence on purchase and WOM intentions. The study assists in developing successful s-commerce models. Maroofi and collaborators (2012) proposed a conceptual model that examines the consumer observation and impression about security and trust in e-payment system [30]. For testing this conceptual model, data were collected from a sample of 219 consumers in Iran. The investigation is considered a theoretical basis and provides practical guidelines for dealing with se- 
curity of e-payment system. Rouibah (2012) conducted a theoretical model to investigate the influence of a set of variables namely; internet experience, personal innovativeness, familiarity, propensity to trust, and presence of third party seal, on intention when using e-payment system through the surrogated variables; perceived enjoyment, perceived risk and perceived trust [31]. Data were gathered from a sample of 150 online questionnered respondents and another paper-based questionnered sample of 200 respondents. The study focused on customer trust and perceived enjoyment for investigating the impact of the external variables (personal innovativeness, familiarity, propensity to trust, and presence of third party seal). This study might assist in encouraging onlinepayment websites trust and acceptance especially in Arab countries.

Lim (2013) explained the buyers process when making an online purchase from a digital market by developing a theory concerning the online buyer behavior [32]. Testing the theory was carried out by gathering data from mall-intercept systematic sampling, and analyzing them was made using structural equation modeling. The results showed that perceptions of value, ease of use, and the usefulness of online buying govern buyers attitude to online shopping. Moreover, the study found that, buyers experience had a very high impact on their online shopping trust. Jarollahi (2013) found that most of Northern Cyprus people agreed with all aspects of EPS [33]. The investigation in this dissertation was carried out with respondents from 18 different countries, and they all have agreed on EPS as an efficient and useful way for payment.

Aigbe and Akpojaro (2014) studied the relationship between vulnerability and security level and their effect on consumer or user confidence in EPS [34]. Nuri (2014) also studied the role of a set of factors like: profitable receipts, security receipts, hidden receipts, high quality service, high quality networks, internet quality, security and trust [35]. Security and trust were found to play an important role in attracting and gaining loyalty of customers. A new conceptual model was introduced after reviewing a number of studies in the literature. This model has proven the direct impact of said factors on customers acceptance of E-banking. The results showed that in order to establish the link and relationship with different organizations, e-banking was a necessary constituent.

Having reviewed some important and relevant studies related to antecedents and outcomes of customers' perceived trust, one can say that the majority of the studies focused on trust as a main factor. Table 1 shows a summary of the literature review.

To achieve the goals of this study, eleven main hypotheses are developed. These hypotheses are:

H1: Perceived reputation has a positive effect on trust.

H2: Perceived privacy has a positive effect on trust.

H3: Perceived size has a positive effect on trust.

H4: Perceived security has a positive effect on trust.

H5: Perceived usefulness has a positive effect on trust.

H6: Familiarity with the web has a positive effect on trust.

H7: Perceived ease of use has a positive effect on trust.

H8: Perceived trust has a positive effect on purchase intention to use EPS.

H9: Perceived trust has a positive effect on actual purchase using credit cards.

H10: Perceived trust has a positive effect on actual purchase using cash on delivery.

H11: Perceived trust has a positive effect on actual purchase using PayPal.

Figure 1 demonstrates the research's conceptual framework and the hypothesized relationships between the adopted constructs.

\section{Research Methodology}

\subsection{Instrument Development}

As the current research aims at exploring the impact of key antecedents of customers' perceived trust on purchase intention to use EPS, actual purchase using credit cards, actual purchase using cash on delivery, and actual purchase using PayPal; it is designed as an empirical study in which relationships between variables would be tested using multifaceted scales adopted from several previous researches. The basis for data collection and analysis is a field study in which respondents answered all items on a five point Likert-scales ranging from 1 (strongly disagree) to 5 (strongly agree). Furthermore, elements used to consider each of the constructs were primarily obtained from prior research. These elements provided a valuable source for data gathering and measurement as their reliability and validity had been verified through previous research and peer reviews. The variables of Perceived Reputation (PR) and Perceived Size (PS) were adapted from [36] [37]. Perceived privacy (PP) was adapted from [20]. Perceived Security (PC) and Perceived Trust (PT) were adapted from [38]. Perceived 
Table 1. Literature review summary.

\begin{tabular}{|c|c|c|c|c|}
\hline Study title & Year and author & Data source & Intrested factors & Results \\
\hline $\begin{array}{c}\text { The role of familiarity and } \\
\text { trust }\end{array}$ & [18] & Survey & $\begin{array}{c}\text { Trust and familiarity on } \\
\text { E-comerce }\end{array}$ & $\begin{array}{l}\text { Customer behavioral } \\
\text { intentions are highly } \\
\text { affected by trust } \\
\text { and familiarity. }\end{array}$ \\
\hline $\begin{array}{c}\text { Toward a Generic Model } \\
\text { of Trust for Electronic } \\
\text { Commerce. }\end{array}$ & [19] & NA & $\begin{array}{l}\text { Trust on payment and } \\
\text { cross-border trading. }\end{array}$ & $\begin{array}{l}\text { A generic model of trust } \\
\text { for E-commerce to start a } \\
\text { transaction over personal } \\
\text { level of trust. }\end{array}$ \\
\hline $\begin{array}{l}\text { Perceived information } \\
\text { security, financial liability } \\
\text { and consumer trust in } \\
\text { electronic commerce } \\
\text { transactions }\end{array}$ & [20] & $\begin{array}{l}\text { The study was } \\
\text { applied on } 179 \\
\text { consumer }\end{array}$ & $\begin{array}{c}\text { Security and } \\
\text { E-commerce trust }\end{array}$ & $\begin{array}{l}\text { Minimal effect of financial } \\
\text { liability on customers' trust } \\
\text { in E-commerce }\end{array}$ \\
\hline $\begin{array}{l}\text { The development of initial } \\
\text { trust in an online company } \\
\text { by new customers }\end{array}$ & [21] & $\begin{array}{l}\text { Questionnaire in } \\
\text { the field of study }\end{array}$ & $\begin{array}{l}\text { Trust development in } \\
\text { web-based company } \\
\text { after their first visit }\end{array}$ & $\begin{array}{l}\text { Perceived company } \\
\text { reputation,willingness to } \\
\text { customize products, } \\
\text { usefulness, ease of use, } \\
\text { and security had a high } \\
\text { impact on the initial trust } \\
\text { and service highly } \\
\text { impact initial trust. }\end{array}$ \\
\hline $\begin{array}{l}\text { Beyond concern-a } \\
\text { privacy-trust-behavioral } \\
\text { intention model of } \\
\text { electronic commerce }\end{array}$ & [22] & $\begin{array}{l}200 \text { subjects were } \\
\text { investigated by } \\
\text { two E-commerece } \\
\text { sites differe in } \\
\text { privacy } \\
\text { dimensions }\end{array}$ & $\begin{array}{c}\text { trust-behavioral } \\
\text { intention of E-comerece }\end{array}$ & $\begin{array}{l}\text { The model was strongly } \\
\text { supported by the study }\end{array}$ \\
\hline $\begin{array}{c}\text { The concept of security } \\
\text { and trust in electronic } \\
\text { payments }\end{array}$ & [3] & NA & $\begin{array}{l}\text { Trust and security in } \\
\text { E-Payment system }\end{array}$ & $\begin{array}{l}\text { Trust and security are } \\
\text { important and essential for } \\
\text { any E-payment systems. }\end{array}$ \\
\hline $\begin{array}{l}\text { Consumer trust in } \\
\text { e-commerce in the United } \\
\text { States, Singapore and } \\
\text { China }\end{array}$ & [23] & $\begin{array}{l}\text { Samples from } \\
\text { United States, } \\
\text { Singapore and } \\
\text { China }\end{array}$ & $\begin{array}{c}\text { Antecedents and } \\
\text { consequences of } \\
\text { consumer trust }\end{array}$ & $\begin{array}{l}\text { Reputation and system } \\
\text { assurance of the Internet } \\
\text { vendor have positive } \\
\text { relation to consumer trust. } \\
\text { The perceived risk is in } \\
\text { negative relationship with } \\
\text { consumer trust. while it has } \\
\text { a positive relationship with } \\
\text { attitude }\end{array}$ \\
\hline $\begin{array}{l}\text { A trust-based consumer } \\
\text { decision-making model in } \\
\text { electronic commerce: The } \\
\text { role of trust, perceived } \\
\text { risk, and their antecedents }\end{array}$ & [24] & $\begin{array}{l}\text { Data set is a } \\
\text { behavioral data } \\
\text { collected via a } \\
\text { web survey }\end{array}$ & $\begin{array}{l}\text { Trusting process that a } \\
\text { consumer use when } \\
\text { purchasing from a } \\
\text { given site }\end{array}$ & $\begin{array}{l}\text { Trusting the Website is } \\
\text { highly affected by } \\
\text { consumer disposition to } \\
\text { trust, reputation, privacy } \\
\text { concerns, security concerns, } \\
\text { the information quality of } \\
\text { the Website, and the } \\
\text { company's reputation. } \\
\text { Meanwhile, the existance of } \\
\text { a third-party has a little } \\
\text { impact on consumer trust. }\end{array}$ \\
\hline $\begin{array}{l}\text { The study on the } \\
\text { influential factors of } \\
\text { electronic payment system } \\
\text { adoption }\end{array}$ & [25] & NA & $\begin{array}{l}\text { Security, easeof use, } \\
\text { trust, interporability, } \\
\text { regularity issues, and } \\
\text { added service }\end{array}$ & $\begin{array}{l}\text { A lot of effort should be } \\
\text { done to come up with a } \\
\text { common trust between sells } \\
\text { and buyers of online } \\
\text { shopping. }\end{array}$ \\
\hline
\end{tabular}




\section{Continued}

From virtual community members to $\mathrm{C} 2 \mathrm{C}$

e-commerce buyers: Trust

in virtual communities and its effect on consumers' purchase intention
An empirical examination of factors influencing the intention to use mobile payment

The effect of perceived trust on electronic commerce: Shopping online for tourism products and services in South Korea.
Effects of various characteristics of social commerce (s-commerce) on consumers' trust and trust performance
Survey of Customers' Conceptions of Security and Trust in E-Payment System
Using the internet search a 340 questionnaires were collected online
Data used in
testing the model
was collected
from Tao-bao VC
Familiarity, perceived similarity, structural assurance, and trust propensity
Ease of use and usefulness.
Factors that affect trust, satisfication, and loyalty
-Important antecedents to trust between VCs members are: familiarity, perceived similarity, structural assurance, and trust propensity.

-Trust in members ability highly affects ability,integrity, and benevolence in the vendor/website.

-Trusting the members intigerity and enevolence stimulates purchase intention while, trust in vendor/website's ability positively affects information regaining intention and purchase intention

Strong predictors of the intention to use mobile-payment are: perceived ease of use and usefulness.

They conclude that navigation functionality and perceived security positively affects trust while transaction cost had no effect on it. Moreover, it is also been obvious from the analysis that satisfication had a positive impact on trust and trust in turn, affect customer

loyalty in online shopping of tourism products and services.

Factors that affects Korean consumers trust in (s-commerece)
Data was collected by 371 s-commerce users

Data was collected from a sample of 219 consumers in Iran
Security and trust in e-pyment system
A conceptual model that examines the consumer observation and impresstion about security and trust in e-pyment system 


\section{Continued}

Trust Factors Influencing Intention to Adopt Online Payment in Kuwait

Toward a theory of online buyer behavior using structural equation modeling

Customers' Trust of Electronic Payment System Use in Northern Cyprus

Analysis of Security Issues in Electronic Payment Systems

A study of role of the factors influencing the acceptance of E-banking

A Structural Equation Modeling Approach for Determining Antecedents and Outcomes of Customers' Perceived Trust: An Empirical Study of MarkaVIP Company
Data was

gathered by a sample of 150

online questionnered

respondents and another

paper-based

questionnered

sample of 200

respondents

Gathering data from

mall-intercept systematic sampling

Respondents from 18 different countries

Trust in EPS.

Perceptions of value, ease of use, and the usefulness of online buying

NA-Survey

vulnerability and security level

profitable receipts, security receipts, hidden receipts, high quality service, high quality networks, internet quality, security and trust

Perceived reputation, Perceived privacy, Perceived size,

Perceived security, Perceived usefulness,

Familiarity with the web,

Perceived ease of use,

This research paper S Survey

Perceived trust, Purchase intention to use EPS,

Actual purchase using credit cards, Actual purchase using cash on delivery, Actual purchase using PayPal
Encouraging

online-payment websites

trust and acceptance specially in Arab countries
-Factors govern buyers attitude to online shopping. -Buyers experience had a very high impact on their online shopping trust

most of Northern Cyprus people agreed with all aspects of EPS.

Reveals that electronic payment systems with authentication mechanisms involving two or more authentication factors tend to be more secured, reduced fraud vulnerability, and boost users' confidence in using electronic payment systems

-Security and trust play the main role in attract and gain loyalty of customers.

-A new conceptual model was introduced after passing over multiple studies.

-This model proofs the direct impact of mentioned factors on customers acceptance of E-banking.

-confirming the seven main hypotheses of the research that were related to testing -Four factors (reputation, security, familiarity, and ease of use) were found to have a positive effect

-The remaining three were not (privacy, size and usefulness).

-having perceived trust meant no preference to any method of payment by the customers.

usefulness (PU) was adapted from [39]. Familiarity with the web (FW) was adapted from [18]. Perceived ease of use (PE) was adapted from [40]. Purchase intention to use EPS (PI), Actual purchase using credit cards (AP), Actual purchase using cash on delivery (AO), Actual purchase using PayPal (AR) were adapted from [26] and 
[29]. Table 2 shows the measured constructs and the items measuring each of those constructs.

\subsection{Research Subjects and Data Collection}

Empirical data for this study were collected through a paper-based survey in Jordan. Specifically, a survey questionnaire was used to gather data for hypotheses testing from MarkaVIP Company. MarkaVIP Company was considered suitable as they trade only on-line, have many customers and accept the different forms of payments that the research intended to investigate. Prior to implementing the survey, the instrument was reviewed by three lecturers specialized in the Management Information Systems (MIS) discipline in order to identify problems with wording, content, and question ambiguity. After some changes were made based on their suggestions, the modified questionnaire was piloted on five customers who shopped from MarkaVIP regularly. Based on the feedback of this piloting stage, minor edits were introduced to the survey questions, and the questionnaires were distributed to the sample customers, who had prior experience with MarkaVIP. After eliminating incomplete surveys, 214 eligible surveys were obtained. The demographic data of the respondents are reported in Table 3.

Overall, the sample consisted of slightly more females (55.1\%), age of 18 years-less than 30 years (87\%), less than 5 times shopping from MarkaVIP (56.5\%) and 23.4\% shopping from MarkaVIP 20 times and more, spent less than $\$ 100$ (45.3\%), followed by $25.7 \%$ who spent $\$ 300$ and more, and most of the participants had under $\$ 5000$ household income per year (44.9\%), followed by $22.4 \%$ did not want to explore their yearly income.

\section{Research Results}

The theoretical framework was tested using SEM techniques by utilizing Analysis of Moment Structures (AMOS) 20 software for data analysis. SEM can be divided into two sub-models: a measurement model and a structural model. While the measurement model defines relationships between the observed and unobserved variables, the structural model identifies relationships among the unobserved/latent variables by specifying which latent variables directly or indirectly influence changes in other latent variables in the model [41]. Furthermore, the structural equation modeling process consisted of two components: validating the measurement model and

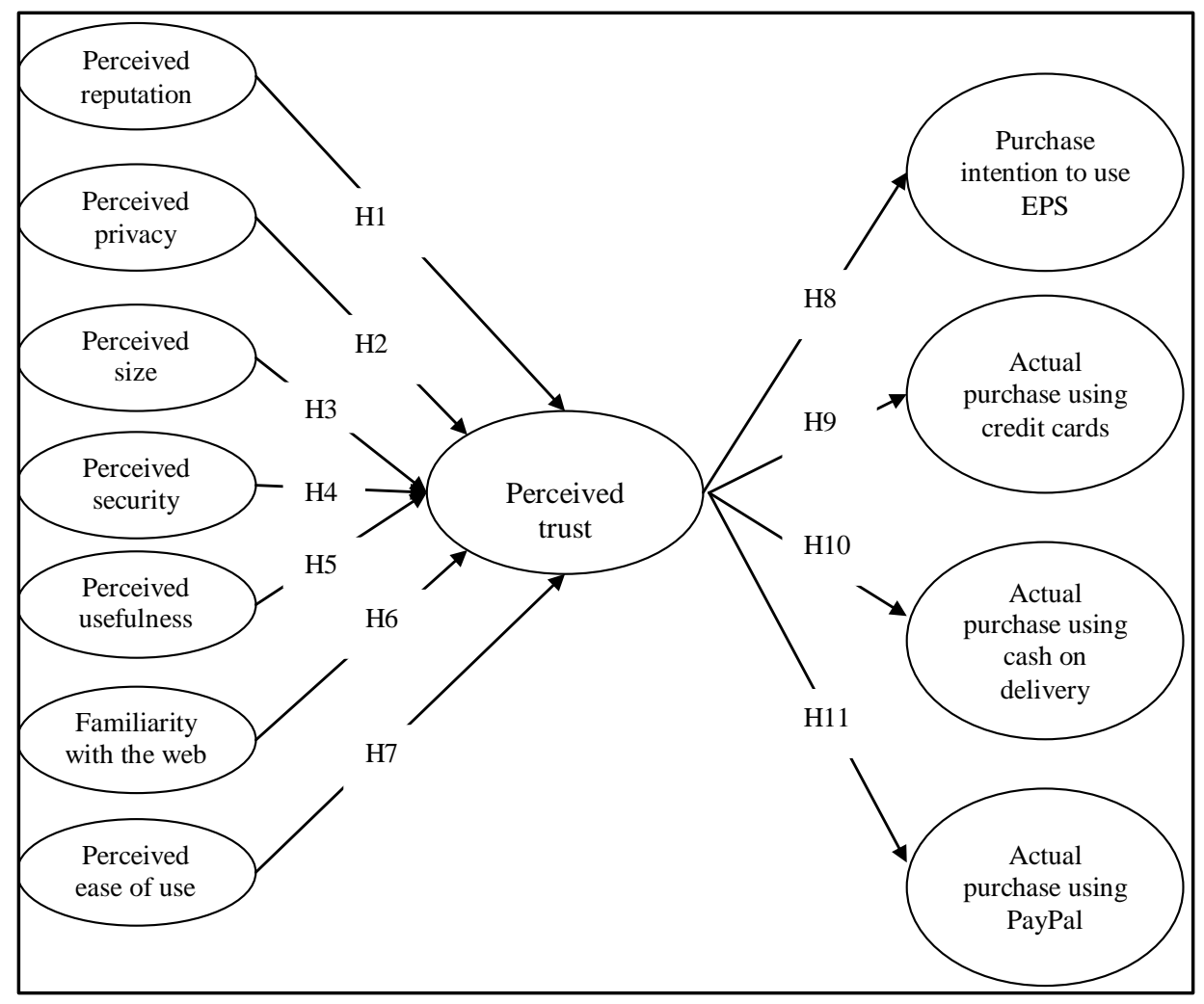

Figure 1. Research model. 
Table 2. Constructs and measurement items.

\begin{tabular}{|c|c|c|}
\hline Construct & Measurement items & Adapted from \\
\hline $\begin{array}{l}\text { Perceived reputation } \\
\text { (PR) }\end{array}$ & $\begin{array}{l}\text { PR1: MarkaVIP is very popular online shopping site. } \\
\text { PR2: MarkaVIP is very reliable online shopping site. } \\
\text { PR3: MarkaVIP is very honest online shopping site. } \\
\text { PR4: MarkaVIP is known to be concerned about customers. }\end{array}$ & [36] and [37] \\
\hline $\begin{array}{l}\text { Perceived privacy } \\
\text { (PP) }\end{array}$ & $\begin{array}{l}\text { PP1: I am confident that I know all parties who collect the information I provide } \\
\text { during a transaction with MarkaVIP. } \\
\text { PP2: I know what information I need to provide during a transaction with MarkaVIP. } \\
\text { PP3: I believe I can subsequently verify the information I provide during a } \\
\text { transaction with MarkaVIP. } \\
\text { PP4: I believe that MarkaVIP will not disclose my information without my consent. }\end{array}$ & [20] \\
\hline $\begin{array}{l}\text { Perceived size } \\
\text { (PS) }\end{array}$ & $\begin{array}{l}\text { PS1: MarkaVIP is a very large company. } \\
\text { PS2: MarkaVIP is one of the industry’s biggest suppliers on the Web. } \\
\text { PS3: MarkaVIP is a big player in the market. } \\
\text { PS4: MarkaVIP has regional and global presence. }\end{array}$ & [36] and [37] \\
\hline $\begin{array}{l}\text { Perceived security } \\
\text { (PC) }\end{array}$ & $\begin{array}{l}\text { PC1: I think MarkaVIP EPS is secured. } \\
\text { PC2: I think the information relating to user and EPS transactions in MarkaVIP are } \\
\text { secure. } \\
\text { PC3: I believe inappropriate parties will not be able to view the information I provide } \\
\text { during a transaction on MarkaVIP. } \\
\text { PC4: I do not fear hacker invasions into MarkaVIP EPS. }\end{array}$ & [38] \\
\hline $\begin{array}{l}\text { Perceived usefulness } \\
\text { (PU) }\end{array}$ & $\begin{array}{l}\text { PU1: Shopping from MarkaVIP improves my shopping performance. } \\
\text { PU2: Shopping from MarkaVIP increases my shopping productivity. } \\
\text { PU3: Shopping from MarkaVIP increases my shopping effectiveness. } \\
\text { PU4: Shopping from MarkaVIP is very useful. }\end{array}$ & [39] \\
\hline $\begin{array}{c}\text { Familiarity with the } \\
\text { web (FW) }\end{array}$ & $\begin{array}{l}\text { FW1: Overall, I am familiar with the MarkaVIP site. } \\
\text { FW2: I am familiar with searching for items on MarkaVIP site. } \\
\text { FW3: I am familiar with the process of purchasing from MarkaVIP site. } \\
\text { FW4: I am familiar with buying products from MarkaVIP site. }\end{array}$ & {$[18]$} \\
\hline $\begin{array}{l}\text { Perceived ease of } \\
\text { use } \\
\text { (PE) }\end{array}$ & $\begin{array}{l}\text { PE1: Learning to use MarkaVIP site would be easy for me. } \\
\text { PE2: My interaction with MarkaVIP site is clear and understandable. } \\
\text { PE3: It would be easy for me to become skillful when using MarkaVIP site. } \\
\text { PE4: I find MarkaVIP site easy to use. }\end{array}$ & [40] \\
\hline $\begin{array}{l}\text { Perceived trust } \\
\text { (PT) }\end{array}$ & $\begin{array}{l}\text { PT1: I believe that my transactions with MarkaVIP site are likely to be safe. } \\
\text { PT2: My transactions with MarkaVIP site are likely to be reliable. } \\
\text { PT3: Many things may not go wrong with my transactions with MarkaVIP site. } \\
\text { PT4: MarkaVIP site will promptly inform me if any problems occur with my } \\
\text { transaction. } \\
\text { PT5: I am confident that my transactions with MarkaVIP site will be transparent. }\end{array}$ & [38] \\
\hline $\begin{array}{l}\text { Purchase intention } \\
\text { to use EPS (PI) }\end{array}$ & $\begin{array}{l}\text { PI1: I am likely to purchase products from MarkaVIP site. } \\
\text { PI2: Given the opportunity, I would consider purchasing products from MarkaVIP } \\
\text { site in the future. } \\
\text { PI3: It is likely that I will actually purchase products from MarkaVIP site in the near } \\
\text { future. } \\
\text { PI4: Given the opportunity, I intend to purchase products from MarkaVIP site. }\end{array}$ & [26] and [29] \\
\hline $\begin{array}{l}\text { Actual purchase } \\
\text { using credit cards } \\
\text { (AP) }\end{array}$ & $\begin{array}{l}\text { AP1: I make online purchase frequently from MarkaVIP site using Credit Cards. } \\
\text { AP2: I make online purchases intensively from MarkaVIP site using Credit Cards. } \\
\text { AP3: Overall, I have made many online purchases from MarkaVIP site using Credit } \\
\text { Cards. } \\
\text { AP4: In the future, I am planning to continue purchasing products using Credit Cards } \\
\text { from MarkaVIP site. }\end{array}$ & [26] and [29] \\
\hline
\end{tabular}




\section{Continued} using cash on delivery (AO)

Actual purchase using PayPal (AR)
AO1: I make online purchase frequently from MarkaVIP site using Cash on Delivery.

AO2: I make online purchases intensively from MarkaVIP site using Cash on Delivery.

AO3: Overall, I have made many online purchases from MarkaVIP site using Cash on Delivery.

AO4: In the future, I am planning to continue purchasing products using Cash on

Delivery from MarkaVIP site.

AR1: I make online purchase frequently from MarkaVIP site using PayPal.

AR2: I make online purchases intensively from MarkaVIP site using PayPal.

AR3: Overall, I have made many online purchases from MarkaVIP site using PayPal.

AR4: In the future, I am planning to continue purchasing products using PayPal from

[26] and [29]

\section{Table 3. Demographic data for respondents.}

\begin{tabular}{|c|c|c|}
\hline Category & Frequency & Percentage \% \\
\hline \multicolumn{3}{|l|}{ Gender } \\
\hline Male & 96 & 44.9 \\
\hline Female & 118 & 55.1 \\
\hline Total & 214 & 100 \\
\hline \multicolumn{3}{|l|}{ Age } \\
\hline 18 years - less than 30 years & 186 & 87.0 \\
\hline 30 years - less than 40 years & 21 & 9.8 \\
\hline 40 years - less than 50 years & 2 & 0.9 \\
\hline 50 years and above & 5 & 2.3 \\
\hline Total & 214 & 100 \\
\hline \multicolumn{3}{|c|}{ Shopping from MarkaVIP (during last year) } \\
\hline Less than 5 & 121 & 56.5 \\
\hline 5-less than 10 & 25 & 11.7 \\
\hline 10-less than 20 & 18 & 8.4 \\
\hline 20 and more & 50 & 23.4 \\
\hline Total & 214 & 100 \\
\hline \multicolumn{3}{|l|}{ Money spent (during last year) } \\
\hline Less than $\$ 100$ & 97 & 45.3 \\
\hline$\$ 100$-less than $\$ 200$ & 40 & 18.7 \\
\hline$\$ 200$-less than $\$ 300$ & 22 & 10.3 \\
\hline$\$ 300$ and more & 55 & 25.7 \\
\hline Total & 214 & 100 \\
\hline \multicolumn{3}{|l|}{ Household income (per year) } \\
\hline Under $\$ 5000$ & 96 & 44.9 \\
\hline$\$ 5000$-less than $\$ 10,000$ & 31 & 14.5 \\
\hline$\$ 10,000$ and more & 39 & 18.2 \\
\hline Do not want to say & 48 & 22.4 \\
\hline Total & 214 & 100 \\
\hline
\end{tabular}


fitting the structural model. While the former is accomplished through confirmatory factor analysis, the latter was accomplished by path analysis with latent variables [42].

Table 4 shows different types of goodness of fit indices in assessing this study initial specified model. It demonstrates that the research constructs fit the data according to the absolute, incremental, and parsimonious model fit measures, comprising chi-square per degree of freedom ratio $\left(\mathrm{x}^{2} / \mathrm{df}\right)$, Incremental Fit Index (IFI), Tucker-Lewis Index (TLI), Comparative Fit Index (CFI), and Root Mean Square Error of Approximation (RMSEA). The researchers examined the standardized regression weights for the research's indicators and found that all indicators had a high loading towards the latent variables. Moreover, since all of these items did meet the minimum recommended value of factor loadings of 0.50; and RMSEA less than 0.10 [43], they were all included for further analysis. Therefore, the measurement model showed a better fit to the data (as shown in Table 3). For instance, $\mathrm{x}^{2} / \mathrm{df}$ and RMSEA was 1.803 , the IFI $=0.86$, TLI $=0.84, \mathrm{CFI}=0.85$; and RMSEA 0.061 indicated better fit to the data considering all loading items.

\subsection{Measurement Model}

Confirmatory factor analysis (CFA) was conducted to check the properties of the instrument items. Indeed, having the final measurement model for all constructs, the next phase was to evaluate them for unidimensionality, reliability, and validity. The outcomes of the measurement model are presented in Table 4, which encapsulates the standardized factor loadings, measures of reliabilities and validity for the final measurement model.

\subsubsection{Unidimensionality}

Unidimensionality is the extent to which the study indicators deviate from their latent variable. An examination of the unidimensionality of the research constructs is essential and is an important prerequisite for establishing construct reliability and validity analysis [44]. Moreover, in line with Byrne (2001), this research assessed unidimensionality using the factor loading of items of their respective constructs [41]. Table 4 shows solid evidence for the unidimensionality of all the constructs that were specified in the measurement model. All loadings were above 0.50 , which is the criterion value recommended by [43]. These loadings confirmed that 49 items were loaded satisfactory on their constructs.

\subsubsection{Reliability}

Reliability analysis is related to the assessment of the degree of consistency between multiple measurements of a variable, and could be measured by Cronbach Alpha coefficient and composite reliability [45]. Some scholars (e.g. Bagozzi and Yi, 1988) suggested that the values of all indicators or dimensional scales should be above the recommended value of 0.60 [46]. Table 5 indicates that all Cronbach Alpha values for the twelve constructs exceeded the recommended value of 0.60 (Bagozzi and Yi, 1988) demonstrating that the instrument is reliable [46]. Furthermore, as shown in Table 5, composite reliability values ranged from 0.79 to 0.83 , and were all greater than the recommended value of more than 0.60 (Bagozzi and Yi, 1988) or greater than 0.70 as suggested by Holmes-Smith (2001) [47]. Consequently, according to the above two tests, all the research constructs in this study are considered reliable.

\subsubsection{Content, Convergent, and Discriminant Validity}

Although reliability is considered as a necessary condition of the test of goodness of the measure used in research, it is not sufficient [48] [49], thus validity is another condition used to measure the goodness of a measure. Validity refers to the extent to which an instrument measures is expected to measure or what the researcher wishes to measure [50]. Indeed, the items selected to measure the seven antecedent variables (perceived reputation, perceived privacy, perceived size, perceived security, perceived usefulness, familiarity with the web, and perceived ease of use) besides the other variables (i.e. perceived trust, purchase intention to use EPS, actual purchase using credit cards, actual purchase using cash on delivery, and actual purchase using PayPal) were

Table 4. Measurement model fit indices.

\begin{tabular}{ccccccccc}
\hline Model & $\mathbf{X}^{\mathbf{2}}$ & $\mathbf{d f}$ & $\mathbf{p}$ & $\mathbf{X}^{\mathbf{2}} / \mathbf{d f}$ & $\mathbf{I F I}$ & TLI & CFI & RMSEA \\
\hline Final model & 1912.856 & 1062 & 0.000 & 1.803 & 0.86 & 0.84 & 0.85 & 0.061 \\
\hline
\end{tabular}


Table 5. Properties of the final measurement model.

\begin{tabular}{|c|c|c|c|c|c|c|c|}
\hline $\begin{array}{l}\text { Constructs and } \\
\text { indicators }\end{array}$ & $\begin{array}{l}\text { Std. } \\
\text { loading }\end{array}$ & $\begin{array}{l}\text { Std. } \\
\text { error }\end{array}$ & $\begin{array}{c}\text { Square } \\
\text { multiple } \\
\text { correlation }\end{array}$ & $\begin{array}{c}\text { Error } \\
\text { variance }\end{array}$ & $\begin{array}{c}\text { Cronbach } \\
\text { alpha }\end{array}$ & $\begin{array}{l}\text { Composite } \\
\text { reliability }\end{array}$ & AVE \\
\hline $\begin{array}{l}\text { Perceived } \\
\text { reputation }\end{array}$ & & & & & 0.878 & 0.83 & 0.56 \\
\hline PR1 & 0.818 & $* * *$ & 0.669 & 0.664 & & & \\
\hline PR2 & 0.900 & 0.059 & 0.811 & 0.266 & & & \\
\hline PR3 & 0.830 & 0.062 & 0.689 & 0.468 & & & \\
\hline PR4 & 0.693 & 0.062 & 0.480 & 0.684 & & & \\
\hline Perceived privacy & & & & & 0.785 & 0.80 & 0.51 \\
\hline PP1 & 0.601 & $* * *$ & 0.362 & 0.843 & & & \\
\hline PP2 & 0.798 & 0.157 & 0.637 & 0.539 & & & \\
\hline PP3 & 0.711 & 0.141 & 0.505 & 0.237 & & & \\
\hline PP4 & 0.653 & 0.147 & 0.426 & 0.248 & & & \\
\hline Perceived size & & & & & 0.768 & 0.79 & 0.50 \\
\hline PS1 & 0.722 & $* * *$ & 0.521 & 0.541 & & & \\
\hline PS2 & 0.683 & 0.105 & 0.467 & 0.436 & & & \\
\hline PS3 & 0.664 & 0.104 & 0.441 & 0.450 & & & \\
\hline PS4 & 0.618 & 0.096 & 0.382 & 0.414 & & & \\
\hline Perceived security & & & & & 0.724 & 0.80 & 0.50 \\
\hline PC1 & 0.622 & $* * *$ & 0.387 & 0.458 & & & \\
\hline PC2 & 0.590 & 0.133 & 0.348 & 0.384 & & & \\
\hline PC3 & 0.629 & 0.146 & 0.396 & 0.445 & & & \\
\hline PC4 & 0.677 & 0.158 & 0.458 & 0.309 & & & \\
\hline $\begin{array}{l}\text { Perceived } \\
\text { usefulness }\end{array}$ & & & & & 0.794 & 0.80 & 0.50 \\
\hline PU1 & 0.595 & $* * *$ & 0.354 & 0.636 & & & \\
\hline PU2 & 0.701 & 0.083 & 0.491 & 0.423 & & & \\
\hline PU3 & 0.788 & 0.084 & 0.621 & 0.434 & & & \\
\hline PU4 & 0.742 & 0.087 & 0.550 & 0.499 & & & \\
\hline $\begin{array}{l}\text { Familiarity with } \\
\text { the web }\end{array}$ & & & & & 0.789 & 0.82 & 0.55 \\
\hline FW1 & 0.819 & $* * *$ & 0.291 & 0.499 & & & \\
\hline FW2 & 0.832 & 0.077 & 0.325 & 0.199 & & & \\
\hline FW3 & 0.757 & 0.069 & 0.684 & 0.622 & & & \\
\hline FW4 & 0.730 & 0.066 & 0.677 & 0.288 & & & \\
\hline $\begin{array}{l}\text { Perceived } \\
\text { ease of use }\end{array}$ & & & & & 0.862 & 0.83 & 0.56 \\
\hline PE1 & 0.819 & $* * *$ & 0.672 & 0.510 & & & \\
\hline PE2 & 0.832 & 0.093 & 0.693 & 0.346 & & & \\
\hline PE3 & 0.757 & 0.096 & 0.573 & 0.510 & & & \\
\hline PE4 & 0.730 & 0.094 & 0.533 & 0.573 & & & \\
\hline
\end{tabular}




\begin{tabular}{|c|c|c|c|c|c|c|c|}
\hline \multicolumn{8}{|l|}{ Continued } \\
\hline Perceived trust & & & & & 0.773 & 0.82 & 0.50 \\
\hline PT1 & 0.652 & $* * *$ & 0.425 & 0.419 & & & \\
\hline PT2 & 0.703 & 0.111 & 0.494 & 0.410 & & & \\
\hline PT3 & 0.686 & 0.120 & 0.471 & 0.460 & & & \\
\hline PT4 & 0.600 & 0.127 & 0.360 & 0.471 & & & \\
\hline PT5 & 0.579 & 0.117 & 0.336 & 0.366 & & & \\
\hline $\begin{array}{l}\text { Purchase intention } \\
\text { to use EPS }\end{array}$ & & & & & 0.831 & 0.80 & 0.50 \\
\hline PI1 & 0.767 & $* * *$ & 0.588 & 0.545 & & & \\
\hline PI2 & 0.804 & 0.143 & 0.647 & 0.484 & & & \\
\hline PI3 & 0.739 & 0.134 & 0.546 & 0.574 & & & \\
\hline PI4 & 0.659 & 0.138 & 0.434 & 0.606 & & & \\
\hline $\begin{array}{l}\text { Actual purchase } \\
\text { using credit cards }\end{array}$ & & & & & 0.866 & 0.81 & 0.52 \\
\hline AP1 & 0.767 & $* * *$ & 0.588 & 0.651 & & & \\
\hline AP2 & 0.854 & 0.070 & 0.730 & 0.436 & & & \\
\hline AP3 & 0.796 & 0.069 & 0.634 & 0.558 & & & \\
\hline AP4 & 0.730 & 0.069 & 0.533 & 0.672 & & & \\
\hline $\begin{array}{l}\text { Actual purchase } \\
\text { using cash on } \\
\text { delivery }\end{array}$ & & & & & 0.840 & 0.80 & 0.50 \\
\hline AO1 & 0.784 & $* * *$ & 0.615 & 0.775 & & & \\
\hline AO2 & 0.791 & 0.140 & 0.625 & 0.535 & & & \\
\hline AO3 & 0.818 & 0.138 & 0.669 & 0.445 & & & \\
\hline AO4 & 0.636 & 0.137 & 0.405 & 0.491 & & & \\
\hline $\begin{array}{l}\text { Actual purchase } \\
\text { using PayPal }\end{array}$ & & & & & 0.888 & 0.82 & 0.55 \\
\hline AR1 & 0.822 & $* * *$ & 0.675 & 0.742 & & & \\
\hline AR2 & 0.837 & 0.070 & 0.700 & 0.509 & & & \\
\hline AR3 & 0.847 & 0.069 & 0.717 & 0.460 & & & \\
\hline AR4 & 0.757 & 0.074 & 0.573 & 0.494 & & & \\
\hline
\end{tabular}

validated and reused from previous researches. Therefore, the researchers relied upon a pre-used scale that was developed from other researchers for enhancing the validity of the scale. In addition, the questionnaire items were reviewed by three instructors of the Business Faculty at the University of Jordan. The feedback from the chosen group for the pre-test contributed to enhanced content validity of the instrument. Moreover, in order to enhance the content validity of the instrument, five customers who shopped from MarkaVIP regularly were asked to give their feedback about the questionnaire, thus confirming that the knowledge presented in the content of each question was relevant to the studied topic [51].

In addition, as convergent validity test is necessary in the measurement model to determine if the indicators in a scale load together on a single construct; discriminant validity test is another main requirement to verify if the items developed to measure different constructs are actually evaluating those constructs. As shown in Table 5, all items were significant and had loadings more than 0.50 on their underlying constructs. Moreover, the standard errors for the items ranged from 0.059 to 0.158 and all the item loadings were more than twice their standard error. Discriminant validity was considered using several tests. First, it could be examined in the measurement model by investigating the shared average variance extracted (AVE) by the latent constructs. The correla- 
tions among the research constructs could be used to assess discriminant validity by examining if there were any extreme large correlations among them which would imply that the model has a problem of discriminant validity. If the AVE for each construct exceeds the square correlation between that construct and any other constructs then discriminant validity is occurred [52]. As shown in Table 5, this study showed that the AVEs of all the constructs were equal or above the suggested level of 0.50 , implying that all the constructs that ranged from 0.50 to 0.56 were responsible for more than 50 percent of the variance in their respected measurement items, which met the recommendation that AVE values should be at least 0.50 for each construct [46] [47]. Furthermore, as shown in Table 6, discriminant validity was confirmed as the AVE values were more than the squared correlations for each set of constructs. Thus, the measures significantly discriminate between the constructs.

\subsection{Structural Model and Hypotheses Testing}

Following the two-phase SEM technique, the measurement model results were used to test the structural model, including paths representing the proposed associations among research constructs. In addition, in order to examine the structural model it is essential to investigate the statistical significance of the standardized regression weights (i.e. t-value) of the research hypotheses (see Table 7); and the coefficient of determination $\left(\mathrm{R}^{2}\right.$ ) for the research endogenous variables as well. The coefficient of determination for perceived trust, purchase intention to use EPS, actual purchase using credit cards, actual purchase using cash on delivery, and actual purchase using PayPal were $0.30,0.28,0.15,0.20$, and 0.13 respectively, which indicates that the model does moderately account for the variation of the proposed model. Also, as shown in Table 6, several antecedents of customers' perceived trust on MarkaVIP Company were accepted (i.e. H1, H4, H6, and H7) while H2, H3, and H5 were rejected. However, the effects of customers' perceived trust on purchase intention to use EPS, actual purchase using credit cards, actual purchase using cash on delivery, and actual purchase using PayPal were all significant; therefore, H8, H9, H10, and H11 were supported.

\section{Discussion and Conclusion}

Investigating methods of payments has always been an issue of concern for researchers. Why would some potential buyers continue to prefer performing physical payments? The issue of trust or lack of it was a major consideration especially in e-payments. This was attributed to a number of factors including malfunctioning, potential fraud and unavailability of e-payment means. Researchers pursued the matter of interest by carrying out more researches to understand the lack of trust concerns by potential users.

This research constitutes an addition to the area of security and trust as it has focused on studying perceived

Table 6. AVE and square of correlations between constructs.

\begin{tabular}{|c|c|c|c|c|c|c|c|c|c|c|c|c|}
\hline Constructs & PR & PP & PS & PC & PU & FW & PE & PT & PI & AP & AO & $\mathbf{A R}$ \\
\hline (PR) & 0.56 & & & & & & & & & & & \\
\hline (PP) & 0.49 & 0.51 & & & & & & & & & & \\
\hline (PS) & 0.45 & 0.47 & 0.50 & & & & & & & & & \\
\hline (PC) & 0.51 & 0.45 & 0.46 & 0.50 & & & & & & & & \\
\hline (PU) & 0.45 & 0.50 & 0.44 & 0.48 & 0.50 & & & & & & & \\
\hline (FW) & 0.47 & 0.52 & 0.40 & 0.46 & 0.49 & 0.55 & & & & & & \\
\hline (PE) & 0.48 & 0.46 & 0.43 & 0.45 & 0.49 & 0.52 & 0.56 & & & & & \\
\hline (PT) & 0.51 & 0.49 & 0.49 & 0.44 & 0.46 & 0.52 & 0.50 & 0.50 & & & & \\
\hline (PI) & 0.50 & 0.48 & 0.49 & 0.47 & 0.49 & 0.53 & 0.46 & 0.41 & 0.50 & & & \\
\hline (AP) & 0.27 & 0.27 & 0.23 & 0.34 & 0.28 & 0.28 & 0.42 & 0.32 & 0.20 & 0.52 & & \\
\hline (AO) & 0.52 & 0.43 & 0.44 & 0.47 & 0.42 & 0.50 & 0.41 & 0.41 & 0.40 & 0.20 & 0.50 & \\
\hline (AR) & 0.10 & 0.14 & 0.12 & 0.28 & 0.23 & 0.32 & 0.18 & 0.25 & 0.26 & 0.50 & 0.21 & 0.55 \\
\hline
\end{tabular}

Note: Diagonal elements are the average variance extracted for each of the twelve constructs. Off-diagonal elements are the squared correlations between constructs. 
trust surrogated by perceived reputation, perceived privacy, perceived size, perceived security, perceived usefulness, familiarity with the web and perceived ease of use. The impacts of the perceived trust on purchase intention to use EPS, on actual purchase using credit cards, on actual purchase using cash on delivery and on actual purchase using PayPal were also studied.

The following Table 8 summarizes the results of hypotheses testing:

1) H1: Perceived reputation has a positive effect on trust.

This hypothesis was supported which seemed relatively logical considering that one would expect some additional trust by the customer when the seller (MarkaVip in our case) had a good reputation as online business. The results concurred with the findings of Gefen (2000) who carried out a survey to study the role of familiarity and trust and found that the customer behavioral intentions were highly affected by those two main factors [18].

2) H2: Perceived privacy has a positive effect on trust and H3: Perceived size has a positive effect on trust.

Both hypotheses were not supported which indicated that customers did not pay much attention to the issues of privacy and size of company. The MarkaVip had reputation and perhaps customers assumed that others who had made purchases from the company helped develop this reputation which would have meant a not small company that cared about retaining customers and gaining their trusts. This implied that the later customers

Table 7. Summary of proposed results for the theoretical model.

\begin{tabular}{|c|c|c|c|c|}
\hline Research proposed paths & $\begin{array}{c}\text { Coefficient } \\
\text { value }\end{array}$ & t-value & p-value & $\begin{array}{c}\text { Empirical } \\
\text { evidence }\end{array}$ \\
\hline H1: Perceived reputation $\rightarrow$ perceived trust & 0.071 & 2.071 & 0.038 & Supported \\
\hline H2: Perceived privacy $\rightarrow$ perceived trust & 0.004 & 0.096 & 0.924 & Not supported \\
\hline H3: Perceived size $\rightarrow$ perceived trust & 0.036 & 0.862 & 0.389 & Not supported \\
\hline H4: Perceived security $\rightarrow$ perceived trust & 0.260 & 6.038 & 0.000 & Supported \\
\hline H5: Perceived usefulness $\rightarrow$ perceived trust & 0.033 & 0.817 & 0.414 & Not supported \\
\hline H6: Familiarity with the web $\rightarrow$ perceived trust & 0.098 & 2.727 & 0.006 & Supported \\
\hline H7: Perceived ease of uses $\rightarrow$ perceived trust & 0.248 & 6.408 & 0.000 & Supported \\
\hline H8: Perceived trust $\rightarrow$ purchase intention to use EPS & 0.706 & 9.006 & 0.000 & Supported \\
\hline H9: Perceived trust $\rightarrow$ actual purchase using credit cards & 0.362 & 3.345 & 0.000 & Supported \\
\hline H10: Perceived trust $\rightarrow$ actual purchase using cash on delivery & 0.639 & 7.352 & 0.000 & Supported \\
\hline H11: Perceived trust $\rightarrow$ actual purchase using PayPal & 0.309 & 2.664 & 0.008 & Supported \\
\hline
\end{tabular}

Table 8. Summary of hypotheses testing.

\begin{tabular}{|c|c|}
\hline Hypothesis & Empirical evidence \\
\hline H1: Perceived reputation $\rightarrow$ perceived trust & Supported \\
\hline H2: Perceived privacy $\rightarrow$ perceived trust & Not supported \\
\hline H3: Perceived size $\rightarrow$ perceived trust & Not supported \\
\hline H4: Perceived security $\rightarrow$ perceived trust & Supported \\
\hline H5: Perceived usefulness $\rightarrow$ perceived trust & Not supported \\
\hline H6: Familiarity with the web $\rightarrow$ perceived trust & Supported \\
\hline H7: Perceived ease of uses $\rightarrow$ perceived trust & Supported \\
\hline H8: Perceived trust $\rightarrow$ purchase intention to use EPS & Supported \\
\hline H9: Perceived trust $\rightarrow$ actual purchase using credit cards & Supported \\
\hline H10: Perceived trust $\rightarrow$ actual purchase using cash on delivery & Supported \\
\hline H11: Perceived trust $\rightarrow$ actual purchase using PayPal & Supported \\
\hline
\end{tabular}


(lagers) trusted the experience of the initial risk takers; otherwise, it would have resulted in giving the company bad reputation. Chellappa and Pavlou (2002) studied the perceived information security and its effect on trust [20]. Their conclusion was that it had minimum effect. The reputation might have been the influencing factor not to pay attention to the size of the company by the customer. Koufaris and Hampton-Sosa (2004) have also concluded that the company reputation and privacy concerns have affected the trust [21].

3) H4: Perceived security has a positive effect on trust.

This hypothesis was supported which meant that customers paid attention to the important of security was a primary factor that influenced their trust. This was a common finding by the majority of studies (e.g. Tsiakis and Sthephanides, 2005; Kim et al., 2008; Kim and Mirusmonov, 2010) [3] [27] [28].

4) H5: Perceived usefulness has a positive effect on trust.

The hypothesis was not supported. Respondents were asked if shopping from MarkaVip improved their performance, increased their shopping productivity, increased their shopping effectiveness or if at all shopping from MrkaVip was useful. Obviously was in contradiction with the findings of Koufaris and Zicklin (2002) who reported that the perceived usefulness did affect trust [39].

5) Hypotheses H6 and H7 were supported. This meant that respondents envisaged that familiarity with the web and perceived ease of use had positive effects on perceived trust. In addition, all remaining hypotheses H8-H11 were also supported which meant that the Perceived trust did have positive effects on purchase intention to use EPS, actual purchase using credit cards, actual purchase using cash on delivery and on actual purchase using PayPal.

The common observation is that the perceived trust would mean making the purchase regardless of the method of payment (using EPS, credit cards, cash on delivery or using PayPal). Trust therefore would imply acceptance which also seems to be a common theme in the findings of most relevant prior researches.

Each of the elements of the construct in this study was obtained from prior research, which provided a valued source for data gathering and measurement. Therefore, the reliability and validity of these elements have been verified through previous research and peer reviews. The data were collected from customers of MarkaVip using a paper-based a questionnaire with a sample size 214 from an unknown population of the customers of MarkaVip. The questionnaire was reviewed by lecturers specialized in Management Information Systems (MIS) in order to identify problems with wording, content, and question ambiguity. The modified questionnaire was then piloted on five customers who had shopped from MarkaVip regularly. The final questionnaire was distributed. Structural equation modeling technique was used to analyze the data and study the causal relationships.

As discussed above, eight of the eleven hypotheses were supported. The perceived reputation and security as well as usefulness and ease of use were all important factors with influence on perceived trust. However, perceived privacy, size and usefulness were found not to have similar effects on perceived trust. As for the methods of payment, the customers did not differentiate in their attitude to using any of them once the trust for the company was perceived.

Contributions of this study are useful for academia, MarkaVip and perhaps other similar companies. Results of the analysis may help establish a distinctive strategy to gain trust and ultimately improve performance. The results demonstrate that customers are after gaining trust and are more concerned with particular factors that are worth focusing on by companies.

However, the study has some limitations. The first limitation is that this research is the first attempt for clearly investigating the trust factors in the Jordanian/Arabic context. Secondly, this study used a sample of customers who were willing to participate and respond regarding their attitudes. The proposed theoretical research model might be applied among other groups or customers in other countries in the region. Thirdly, although the response rate for this research was adequate for the primary conditions of statistical analyses, the percentage of those who did not respond was still observable. Therefore, descriptive statistics, confirmatory factor, unidimensionality, reliability, content, convergent, and discriminant validity have to be further investigated and confirmed by other researchers. Finally, the results from this survey were limited to Jordan and to MarkaVip customers in particular. Potential cultural limitation may exist and future research in different cultural contexts might shed further light if we are to be able to generalize or may be having to modify the research model. Therefore, it might be wise to interpret the results of this study with some caution.

\section{References}

[1] Yu, H.-C., Hsi, K.-H. and Kuo, P.-J. (2002) Electronic Payment Systems: An Analysis and Comparison of Types. 
Technology in Society, 24, 331-347.

[2] Peha, J.M. and Khamitov, I.M. (2004) PayCash: A Secure Efficient Internet Payment System. Electronic Commerce Research and Applications, 3, 381-388.

[3] Tsiakis, T. and Sthephanides, G. (2005) The Concept of Security and Trust in Electronic Payments. Computers and Security, 24, 10-15.

[4] Maqableh, M. (2012) Analysis and Design Security Primitives Based on Chaotic Systems for eCommerce. Durham University.

[5] Mallat, N. (2007) Exploring Consumer Adoption of Mobile Payments-A Qualitative Study. Journal of Strategic Information Systems, 16, 413-432. http://dx.doi.org/10.1016/j.jsis.2007.08.001

[6] Masa'deh, R., Gharaibeh, A., Maqableh, M. and Karajeh, H. (2013) An Empirical Study of Antecedents and Outcomes of Knowledge Sharing Capability in Jordanian Telecommunication Firms: A Structural Equation Modeling Approach. Life Science Journal, 10, 2284-2296.

[7] Sumanjeet, S. (2009) Emergence of Payment Systems in the Age of Electronic Commerce: The State of Art. Global Journal of International Business Research, 17-36.

[8] Maqableh, M.M. (2010) Secure Hash Functions Based on Chaotic Maps for E-Commerce Applications. International Journal of Information Technology and Management Information System (IJITMIS), 1, 12-22.

[9] Nor, K.M. and Pearson, J.M. (2010) The Influence of Trust on Internet Banking Acceptance. Journal of Internet Banking and Commerce, 12.

[10] Tsai, W.H., Huang, B.Y., Liu, J.Y., Tsaur, T.S. and Lin, S.J. (2010) The Application of Web ATMs in e-Payment Industry: A Case Study. Expert Systems with Applications, 37, 587-597. http://dx.doi.org/10.1016/j.eswa.2009.05.058

[11] Al-ma'aitah, M. and Shatat, A. (2011) Empirical Study in the Security of Electronic Payment Systems. Journal of Computer Science, 8, 393-401.

[12] Harris, H. (2011) Evidence of Firms’ Perceptions toward Electronic Payment Systems (EPS) in Malaysia. International Journal of Business and Information, 6, 226-245.

[13] Maqableh, M., Samsudin, A. and Alia, M. (2008) New Hash Function Based on Chaos Theory (CHA-1). International Journal of Computer Science and Network Security, 8, 20-27.

[14] Lu, Y., Yang, S., Chau, P.Y.K. and Cao, Y. (2011) Dynamics between the Trust Transfer Process and Intention to Use Mobile Payment Services: A Cross-Environment Perspective. Information and Management, 48, 393-403. http://dx.doi.org/10.1016/j.im.2011.09.006

[15] Gogoski, R. (2012) Payment Systems in Economy—Present End Future Tendencies. Procedia-Social and Behavioral Sciences, 44, 436-445. http://dx.doi.org/10.1016/j.sbspro.2012.05.048

[16] Geva, B. (2013) Global Payment and Settlement Systems. In: Caprio, G., Ed., Handbook of Key Global Financial Markets, Institutions and Infrastructure, Academic Press, Waltham, 513-522. http://dx.doi.org/10.1016/B978-0-12-397873-8.00034-7

[17] Liébana-Cabanillas, F., Sánchez-Fernández, J. and Muñoz-Leiva, F. (2014) The Moderating Effect of Experience in the Adoption of Mobile Payment Tools in Virtual Social Networks: The m-Payment Acceptance Model in Virtual Social Networks (MPAM-VSN). International Journal of Information Management, 34, 151-166. http://dx.doi.org/10.1016/j.ijinfomgt.2013.12.006

[18] Gefen, D. (2000) E-commerce: The Role of Familiarity and Trust. The International Journal of Management Science, 28, 725-737. http://dx.doi.org/10.1016/s0305-0483(00)00021-9

[19] Tan, Y. and Thoen, W. (2001) Toward a Generic Model of Trust for Electronic Commerce. International Journal of Electronic Commerce, 5, 61-74.

[20] Chellappa, R.K. and Pavlou, P.A. (2002) Perceived Information Security, Financial Liability and Consumer Trust in Electronic Commerce Transactions. Logistics Information Management, 15, 358-368. http://dx.doi.org/10.1108/09576050210447046

[21] Koufaris, M. and Hampton-Sosa, W. (2004) The Development of Initial Trust in an Online Company by New Customers. Information and Management, 41, 377-397. http://dx.doi.org/10.1016/j.im.2003.08.004

[22] Liu, C., Marchewka, J.T., Lu, J. and Yu, C.S. (2005) Beyond Concern-A Privacy-Trust-Behavioral Intention Model of Electronic Commerce. Information and Management, 42, 289-304. http://dx.doi.org/10.1016/j.im.2004.01.003

[23] Teo, T.S.H. and Liu, J. (2007) Consumer Trust in E-Commerce in the United States, Singapore and China. Omega, 35, 22-38. http://dx.doi.org/10.1016/j.omega.2005.02.001

[24] Kim, D.J., Ferrin, D.L. and Rao, H.R. (2008) A Trust-Based Consumer Decision-Making Model in Electronic Commerce: The Role of Trust, Perceived Risk, and Their Antecedents. Decision Support Systems, 44, 544-564. 
http://dx.doi.org/10.1016/j.dss.2007.07.001

[25] Zhang, H.M. (2009) The Study on the Influential Factors of Electronic Payment System Adoption. 2009 International Conference on Management Science and Engineering, ICMSE 2009, Moscow, 14-16 September 2009, 106-111. http://dx.doi.org/10.1109/ICMSE.2009.5317578

[26] Lu, Y., Zhao, L. and Wang, B. (2010) From Virtual Community Members to C2C E-Commerce Buyers: Trust in Virtual Communities and Its Effect on Consumers' Purchase Intention. Electronic Commerce Research and Applications, 9, 346-360. http://dx.doi.org/10.1016/j.elerap.2009.07.003

[27] Kim, C., Mirusmonov, M. and Lee, I. (2010) An Empirical Examination of Factors Influencing the Intention to Use Mobile Payment. Computers in Human Behavior, 26, 310-322. http://dx.doi.org/10.1016/j.chb.2009.10.013

[28] Kim, M.J., Chung, N. and Lee, C.K. (2011) The Effect of Perceived Trust on Electronic Commerce: Shopping Online for Tourism Products and Services in South Korea. Tourism Management, 32, 256-265. http://dx.doi.org/10.1016/j.tourman.2010.01.011

[29] Kim, S. and Park, H. (2012) Effects of Various Characteristics of Social Commerce (S-Commerce) on Consumers' Trust and Trust Performance. International Journal of Information Management, 33, 318-332. http://dx.doi.org/10.1016/j.ijinfomgt.2012.11.006

[30] Maroofi, F., Hashemi, R., Nargesi, Z. and Branch, K. (2012) Survey of Customers' Conceptions of Security and Trust in E-Payment System. Asian Journal of Business Management, 4, 275-285.

[31] Rouibah, K. (2012) Trust Factors Influencing Intention to Adopt Online Payment in Kuwait. Proceedings of the Southern Association for Information Systems Conference, Atlanta, 23-24 March 2012, 195-202.

[32] Lim, W.M. (2013) Toward a Theory of Online Buyer Behavior Using Structural Equation Modeling. Modern Applied Science, 7, 34-41. http://dx.doi.org/10.5539/mas.v7n10p34

[33] Jarollahi, A.A. (2013) Customers’ Trust of Electronic Payment System Use in Northern Cyprus.

[34] Aigbe, P. and Akpojaro, J. (2014) Analysis of Security Issues in Electronic Payment Systems. International Journal of Computer Applications, 108, 10-14. http://dx.doi.org/10.5120/18946-9993

[35] Nuri, H. (2014) A Study of Role of the Factors Influencing the Acceptance of E-Banking. No. 3, 521-525.

[36] Doney, M. and Cannon, J.P. (1997) An Examination of the Nature of Trust in Buyer-Seller Relationships. Journal of Marketing, 61, 35-51. http://dx.doi.org/10.2307/1251829

[37] Jarvenpaa, S.L., Tractinsky, N. and Vitale, M. (2000) Consumer Trust in an Internet Store. Information Technology and Management, 1, 45-71. http://dx.doi.org/10.1023/A:1019104520776

[38] Kim, C., Tao, W., Shin, N. and Kim, K.S. (2010) An Empirical Study of Customers' Perceptions of Security and Trust in E-Payment Systems. Electronic Commerce Research and Applications, 9, 84-95. http://dx.doi.org/10.1016/j.elerap.2009.04.014

[39] Koufaris, M. (2002) Applying the Technology Acceptance Model and Flow Theory to Online Consumer Behavior. Information Systems Research, 13, 205-223. http://dx.doi.org/10.1287/isre.13.2.205.83

[40] Hoffman, D.L., Novak, T.P. and Peralta, M. (1999) Building Consumer Trust Online. Communications of the ACM, 42, 80-85. http://dx.doi.org/10.1145/299157.299175

[41] Byrne, B.M. (2001) Structural Equation Modeling with AMOS: Basic Concepts, Applications, and Programming. Lawrence Erlbaum Associates, Mahwah.

[42] Kline, R.B. (2005) Principles and Practice of Structural Equation Modeling. 2nd Edition, The Guilford Press, New York.

[43] Newkirk, H.E., Newkirk, H.E., Lederer, A.L. and Lederer, A.L. (2006) The Effectiveness of Strategic Information Systems Planning under Environmental Uncertainty. Information and Management, 43, 481-501. http://dx.doi.org/10.1016/j.im.2005.12.001

[44] Chou, T.C., Chang, P.L., Cheng, Y.P. and Tsai, C.T. (2007) A Path Model Linking Organizational Knowledge Attributes, Information Processing Capabilities, and Perceived Usability. Information and Management, 44, 408-417. http://dx.doi.org/10.1016/j.im.2007.03.003

[45] Hair, J., Black, W., Babin, B., Anderson, R., Tatham, R. and Black, W. (2010) Multivariate Data Analysis. 5th Edition, Vol. 259, Prentice-Hall International Inc., Upper Saddle River.

[46] Bagozzi, R. and Yi, Y. (1988) On the Evaluation of Structural Equation Models. Journal of the Academy of Marketing Science, 16, 74-94. http://dx.doi.org/10.1007/BF02723327

[47] Holmes-Smith, P. (2001) Introduction to Structural Equation Modeling Using LISREL. ACSPRI Winter Training Program, Perth.

[48] Creswell, J.W. (2014) Research Design: Qualitative, Quantitative and Mixed Methods Approaches. 
[49] Sekaran, U. (2003) Research Methods for Business: A Skill-Building Approach. 4th Edition, John Wiley and Sons, Hoboken.

[50] Blumberg, B., Cooper, D.R. and Schindler, P.S. (2005) Business Research Methods, 770.

[51] Masa'deh, R., Shannak, R. and Maqableh, M. (2013) A Structural Equation Modeling Approach for Determining Antecedents and Outcomes of Students' Attitude toward Mobile Commerce Adoption. Life Science Journal, 10, 23212333.

[52] Fornell, C. and Larcker, D.F. (1981) Evaluating Structural Equation Models with Unobservable Variables and Measurement Error. Journal of Marketing Research, 18, 39-50. http://dx.doi.org/10.2307/3151312 